\section{Child delinquency and the prophylaxis of crime in early 20th-century Latin America}

\author{
Andrés Villaveces ${ }^{1}$ and \\ Lisa A. DeRoo²
}

Suggested citation: Villaveces A, DeRoo LA. Child delinquency and the prophylaxis of crime in early 20th-century Latin America. Rev Panam Salud Publica. 2008; 24(6):449-54.

Key words: history, child abuse, violence, crime, Colombia.

\footnotetext{
1 Injury Prevention Research Center, Department of Epidemiology, The University of North Carolina, Chapel Hill, North Carolina, United States of America. Send correspondence and reprint requests to: Andrés Villaveces, Research Assistant Professor, Injury Prevention Research Center, Department of Epidemiology, The University of North Carolina, 137 East Franklin Street, CB7505, Chapel Hill, North Carolina 27599-7505, United States of America; telephone: (919) 966-6625; fax: (919) 966-0466; e-mail: avillav@email.unc.edu

2 Visiting Fellow, Department of Clinical Epidemiology, Geneva University Hospitals, Geneva, Switzerland.
}

The battered child syndrome was first described by Ambroise Tardieu in 1860 (1). It was then absent in the medical literature until almost a century later, when it garnered wide attention following the publications of Caffey (2), Silverman (3), and Kempe (4). During the 80-year gap between Tardieu's research and that of the other authors listed above, a great deal was published on the conditions leading individuals to commit abuses against children and the effect of child maltreatment on juvenile behavior. In addition, from the late 19th century through the early 20th century, there were major developments in forensic sciences and in explanatory theories of behaviors considered "abnormal" or "deviant." Most of these theories came from the fields of psychiatry, anthropology, sociology, and criminology, and many of their authors were physicians.

"Child delinquency and the prophylaxis of crime," a lecture presented by Colombian pediatrician and social hygienist Jorge Bejarano Martínez (1888-1966) at a 1929 conference to benefit the International Committee of the Red Cross, provides insight into early 20th-century views of maltreatment, its consequences for juvenile behavior, and strategies to prevent juvenile delinquency (5). Bejarano served as the first president of the Colombian Red Cross, [a] president of the Colombian National Academy of Medicine, Colombia's first Minister of Hygiene (1946-1949), a member of several international medical organizations, and a politician. His 1929 lecture described his belief that the social and physical context in which individuals lived affected the occurrence of violence. His views echoed those of the "social environment school" (école du milieu social) of Lyon, France, led by Alexandre Lacassagne (French physician and forensic scientist, 1843-1924), which combined biological and social elements to explain child maltreatment and its consequences for children's behavior. Referring to these strategies collectively as the "prophylaxis of crime," Bejarano provided examples from Europe and North America, where these theories were popular in the early 20th century.

While some of Bejarano's ideas resemble current views, many are distinctly different, such as the "theories of degeneration," and notions that infectious diseases were direct causes of violent or criminal behavior. For example, alcohol abuse, currently attributed to multiple causes, including childhood exposure to physical and sexual abuse 
(6), was described by Bejarano as a biologically inherited disease passed on from parents to children that resulted in abnormal or delinquent behaviors through generations of families $(7,8)$. During Bejarano's era, this notion of the "degeneration of families" led to the development of preventive strategies aimed at halting these noxious processes through the rehabilitation of children. As illustrated in Bejarano's text, 20th-century preventative strategies included early interventions based on the recognition of social conditions that were viewed as precursors of violence at the time and are still considered important factors today. This article summarizes the 88-page text of Bejarano's original presentation, using his original subject headings for suggested crime prevention strategies (see "Strategies for the prophylaxis (prevention) of crime"), plus illustrative quotations.

\section{General context of the problem}

Bejarano asserted that "Colombian criminality is a function of [Colombian] culture" (p. 16), based on his belief that "crime is the consequence of the concourse of the physical and social conditions in which the criminal is born and lives" (p. 15). He stressed that "criminality and delinquency in adults or children are not [only] the result of cellular or biological degeneration, but [also] indexes of the pathological, moral, or social states that have induced them" (p. 16), thus echoing Lacassagne's statements that "societies get the criminals they deserve" (7: 193), and "the criminal is like a microbe that develops only if the microbial culture in which it grows is favorable" (7: 193). Bejarano agreed with the prevalent view of the time that criminals were abnormal beings who could be classified in different categories and who needed to be isolated from their noxious environments in order to be rehabilitated. Many physicians promoted the idea that isolation of individuals into healthier, moral environments was especially important for those considered at risk of becoming criminals.

Bejarano defined "the study of crime and its prophylaxis" as a "new aspect of medicine" (p. 17) and emphasized physicians' leading role in the criminal domain, given their responsibility " . . f for pointing out why reactions against social order and transgressions against human laws have appeared suddenly or in permanent ways in the mind or human will" (p. 17). He asserted the physician's "moral obligation to society ... consists of mapping the direction in which physical and moral health should go" (p. 18), while noting the negative influence that social and environmental conditions can have on individuals. Bejarano cited his influences as the work of important criminologists and physi- cians of his time, including Alexandre Lacassagne, Abraham Adolph Baer (German physician and forensic scientist, 1834-1908), and Enrico Ferri (Italian criminologist, 1856-1929). He also incorporated the ideas of Bénédict Augustin Morel (1809-1873), a French psychiatrist who proposed the theory of degeneration to explain criminal or "abnormal" behaviors.

Bejarano believed abusive conditions in childhood could cause delinquency later in life. He described a 1925 visit with students incarcerated at the Paiba Jail for Minors (Cárcel de menores de Paiba), a jail administered by the state but run by a religious order in Bogotá from 1900 until it was demolished in $1935(9,10)$, where he found children under the age of 10 "living in appalling conditions" and subjected to disciplinary devices such as stocks. In their defense, he wrote a letter to the director general of prisons that was later published in Colombia's main national newspaper (El Tiempo, April 25, 1925) (p. 20). The result was a campaign that forced the resignation of the judge for minors, and, more importantly, highlighted the conditions in which children were living in prisons, including their subjection to flagellations and other punishments. Bejarano emphasized the importance of preventing such abuses to avoid later delinquent behaviors by incorporating improved knowledge of the psychological nature of children and the effect of their social context into strategies for the prophylaxis of crime.

\section{The developmental psychology of the child}

In line with Freud and psychologists of his day, Bejarano believed children's brains were different from adult brains (as opposed to being merely small or rudimentary versions of them). He concurred with the notions that children experienced things differently and had less control over subconscious impulses, and their fantasies and ideas were linked less to actual experience than to preconceived views generated by feelings and emotions ("more subjective thoughts") (pp. 27-28). He believed that as a child grows up and social pressures become more intense, there was a need to develop more mechanisms of control in the mind, imposing limits and relying more on experience. "In a normal child," he wrote, "these processes are developed step by step, leaving the world of dreams for that of realities" (p. 29). If this process were interrupted, Bejarano believed, some children remained in a fantasy world of dreams and myths, while others developed the "perverse" characteristic of believing their own confabulations, acting out tricks and prevarications. Bejarano believed there were "enormous differences" between children and adults and hence justified the need for a specialized study of children to 
"evaluate their acts with justice and scientific criteria" (p. 31). He argued that these approaches had "successfully brought about the regeneration of the delinquent or abnormal child" (p. 31).

\section{Disease as a cause of child delinquency}

In Bejarano's day, the concept of "disease" included both infectious agents and behavioral problems, such as addiction. He believed disease could be manifest as not only physical illness but also "low intelligence [or] being turbulent, distracted, unstable, evil, cruel, or delinquent" (p. 32). He asserted that delinquent behaviors were the consequence of either "inherited neuropathies," where suicide and "moral madness" were frequent and no toxic or infectious cause was demonstrable (p. 33), or toxic or infectious agents that began "in conception, where the intoxicated sperm and ovum cannot produce anything normal" (p. 33). He noted that syphilis disrupts the development of the nervous system and causes delinquency, citing the high proportion of delinquent children testing positive for syphilis in Paris. He also causally linked encephalitis and alcoholism to delinquency (as mentioned above, alcoholism was understood as a hereditary factor for delinquency). Other diseases linked to delinquent behaviors were hypo- or hyperthyroidism and "tropical anemia," which was thought to "perturb the nervous system" by affecting endocrine glands, thus leading to delinquent behaviors. Evidence of this was the low school performance of children with "tropical anemia," which was frequently due to parasites. The effects of parasites were considered to be greater in juvenile versus adult nervous systems, and thus the behavioral consequences in children were thought to be more acute. In a new version of Galenic ideas, it was thought at the time that certain chemical alterations of the blood or urine could lead to states such as depression or "turbulent behaviors."

\section{Social factors leading to delinquency}

The main thrust of Bejarano's lecture was the importance of the social causes of delinquency, including the lack of societal protections for children, poor home life, lack of educational opportunities, child labor, abandonment, and child abuse and neglect; these factors could cause delinquency themselves or exaggerate the pathological, hereditary, or functional factors described above. Bejarano viewed social factors as the crucial factor in the etiology of child delinquency in Colombia, and asserted these conditions were markedly different from those in other countries due to Colombia's culture, family structure, and lack of social welfare or child protections (which had been established elsewhere at the time).

Focusing on "irregularly constituted families" (families affected by separation, abandonment, or divorce), he noted that "in $48 \%$ of cases the main factors in family decay are moral and physical neglect, lack of interest in learning and education, the early exploitation of children in unskilled labor, promiscuity, and bad examples" (p. 48). He examined the level of child neglect in Colombia and pointed to the large presence of children living on the street ("street children") in both cities and rural villages. He described Colombia's streets as "extensions of children's homes" and the existence of the street children culture as society's "first step towards abandoning children," and called for the development of children's shelters. Claiming street children were exposed to not only "physical dangers" but also "pathetic" moral consequences, Bejarano saw life on the street as "moral poison for the child," exacerbated by its link with drug abuse.

Bejarano believed education was a crucial component to preventing delinquency and noted there was less delinquency in countries where education was obligatory, such as Uruguay and Argentina. In Colombia, many children had access only to primary school. Bejarano claimed this incomplete education left children unprepared for life and "without institutional guidance." This lack of education was usually compounded by parental neglect and social conditions that forced children to work for their sustenance, often resulting in increased exposure to vice, delinquency, and crime. Bejarano emphasized the importance of youth organizations that could provide children with vocational and psychological guidance.

Bejarano also viewed physical and moral neglect of children as important causes of child delinquency. He cited the cases of the children incarcerated in the Paiba jail in Bogotá, many of whom had been abandoned or whose parents were alcoholics, as evidence. "In many circumstances," he wrote, ". . . our children . . . become delinquent after having been treated with cruelty" (p. 53). He also pointed to strategies implemented in Boston, Massachusetts, where child abusers received severe punishment, and called for the creation of a Colombian organization for the protection of children that would combat this "weak aspect of Colombian society" and return to children the "right to happiness" (p. 54).

Bejarano saw child labor and exploitation as additional factors related to juvenile delinquency, and called for legislation to prevent it. He pointed out the failures of the state in its duty to protect children, as reflected in the lack of appropriate institutions, and asserted physicians were responsible for ensuring the development of these types of services. 


\section{Child delinquency in 1920s Colombia}

Bejarano considered the Paiba jail in the nation's capital a national disgrace and a nest for criminals. Through his firsthand experience visiting child inmates, he was deeply alarmed by the jail's deplorable conditions and the fact that 16560 children had passed through the system in its 23 years of existence (equivalent to 720 per year or almost 2 per day). He criticized the fact that children with minor offenses were mixed together with those who had committed serious crimes and thus could easily learn from the bad influences of others, as well as the lack of services, claiming that "children receive insufficient education and morals from the nuns ... and no vocational or psychological aid is given to them" (p. 60). He questioned how many other children throughout Colombia had had similar experiences and how many had never experienced any institutional or social exposure to crime prevention interventions (the "prophylaxis of crime").

Bejarano was encouraged by the Fontidueño House for Minors in Bello, Antioquia, a new approach to institutionalizing child delinquents that had begun in Colombia in 1920, inspired by the Belgian Central Observation Station for Difficult Children at Mol-Huttes (Etablissement central d'observation pour enfants difficiles de Moll-Huttes) (11). The basic mission of these institutions was to provide educational opportunities, vocational training, medical care, and psychological and social support to troubled youth. Bejarano compared the Fontidueño House for Minors to other such institutions throughout the world, including the Mettray and SaintHilaire "farm schools" (colonies agricoles) in France; operations such as the "Rough House" (Rauhes Haus) reformatory for vagrant children in Germany; the "industrial," "truant," or "reformatory" schools of England; and the Olivera and Marcos Paz reformatories (colonias) in Argentina. Encouraged by criminological evidence from the United States showing the effectiveness of these types of institutions in reducing recidivism, Bejarano promoted their creation throughout Colombia.

\section{Strategies for the prophylaxis (prevention) of crime}

Bejarano presented several strategies for preventing child delinquency that were considered vanguard in his day. These included home visits (to address the needs of children at risk of becoming delinquent or exposed to "moral dangers") and the creation of homes for the poor, observation asylums, temporary homes for child delinquents, and youth courts.
Social services for children in moral danger. Bejarano was inspired by various European approaches to addressing child delinquency, stating ". . nothing could have impressed me in such a deep and indelible way as the social service for children in moral danger that Mme Spitzer and Mme Vicillot [sic] have initiated in Paris" (p. 82). Founded by Olga Spitzer and Marie-Thérèse Vieillot in 1923, the service Bejarano referred to ${ }^{3}$ provided comprehensive services to children while monitoring them in their own homes. Run by dedicated local women, it assessed possible "parental decadence" or "an atmosphere of vice" while also listening to children's concerns. According to Bejarano, the service entailed the following: "Children are received and lodged in this place. Mme Spitzer's social service conducts then a full family survey. An in depth medical exam is also conducted ... If, as is common, they don't have appropriate clothing, this is provided to them" (p. 83). In this context, Bejarano also mentioned the Palais du peuple (Armée du Salut or Salvation Army) in Paris, where the police sent children who were considered vagrants, delinquents, or "abnormal" to avoid sending them to prison. He highlighted the benefits of these programs in terms of not only the social and medical services they provided but also the improved physical conditions in which children could live. He then contrasted this situation with the children from the Colombian jails of Paiba and El Buen Pastor (another jail in Bogotá) and "their indefinable expression of bitterness and hopelessness" (p. 83).

Asylums for the observation of children. As described by Bejarano, these Hungarian and Swiss institutions classified children as those who were "rebellious to any influence," hence requiring asylum, and those who were "susceptible to being modified," who therefore needed "to be subjected to ordinary or correctional education" (p. 84).

Relocation of delinquent children. Regarding the effect of physical surroundings on juvenile behavior, Bejarano wrote the following: "Today, it is almost universally accepted that changing the environment of the child is indispensable for the prophylaxis and treatment of juvenile criminality" (p. 84). He stated that living and working in the countryside was a good strategy for changing unwanted behaviors among youth, citing examples from Belgium and Spain such as the creation of parks and kindergartens for poor children, which replaced "the dangers of the street" with "having leisure in games" (p. 85).

Youth courts. Bejarano believed that delinquent children should not be punished in prisons. "They

\footnotetext{
3 Currently known as the Olga Spitzer Association.
} 
must be subjected to educational treatments, more than to a special regime. The idea of penal punishment tempered by piety, according to Ferdinand Dreyfus [Ferdinand-Camille Dreyfus, journalist, member of parliament, and senator, 1849-1915], has been replaced by the notion of straightening or 'moral orthopedics' - from social adaptation to appropriate discipline and education. Medication can be strong," he emphasized, "but moral incurability must never be presumed" (p. 86).

To support these statements, Bejarano highlighted the beneficial results of the "children's courts" created in 1899 and extended throughout the United States and later Europe. He argued that their success was due in part to the state accepting the principle of family responsibility. Judges of children's courts had the authority to contact parents and hold them responsible for negligence. The state provided for the child only if the parents were incapable of doing so. This legal framework allowed judges to decide what measures could be taken to help children and gave the state the authority to monitor children's behavior using reports commissioned by a corps of probation officers. Bejarano did not advocate similar strategies in Colombia because of his concerns about existing deficiencies in the Colombian penitentiary administration. Instead, he called for the provision of preventive services rather than punitive ones, adding that the provision of social services would provide long-lasting benefits to the children in years to come.

\section{DISCUSSION}

As a pediatrician and social hygienist, Bejarano was especially concerned about the welfare of Colombian children, as demonstrated by his visits to children in Colombian prisons and trips abroad to gain firsthand knowledge of new approaches being tried in Europe and other countries. Although he did not completely break free of the dogma of his day, he did depart from the punitive approach for handling delinquent children that was prevalent in Colombia at the time. Bejarano's focus on preventing "degenerate behavior" and "moral shortcomings" could be viewed as judgmental today. In fact, there may have been discriminatory undercurrents in the way these ideas were implemented. Although he did not mention it explicitly, Bejarano may have adhered to the common view that indigenous cultures were inferior, and that some of their customs and practices were immoral. Such views were prevalent throughout the Americas and Europe at the time. For example, as Colombia's Minister of Hygiene, Bejarano led the prohibition of chicha (an indigenous alcoholic beverage made from fermented corn), as he believed it led to violence (12), yet did not promote similar measures for beer, a more socially acceptable European alcoholic beverage.

Between the delivery of his lecture in 1929 and his death in 1966, Bejarano saw many changes related to child welfare in Colombia. At the time of his lecture, he could not have envisioned the environment of internal conflict and war that has had such a negative impact on Colombian society. Nonetheless, many of the factors he recognized as important in preventing delinquency and violence are still recognized today. For example, drawing from current research worldwide, the 2002 World Report on Violence and Health published by the World Health Organization (WHO) (13) identified abusive parenting, chronic poverty, unemployment, deteriorating physical and social infrastructures, economic and social inequalities, weak policies for protecting children, and social conflicts and war as risk factors for child abuse and neglect. All of these factors are still present in Latin America today, a region with the highest levels of interpersonal violence globally in 2002 (14).

Despite the persistence of violence and underlying social problems, there has been some progress in preventing child abuse and neglect and youth violence in Colombia. The country is a leader in Latin America in developing reliable injury surveillance systems (15) as a step for understanding the magnitude of child abuse and neglect and youth violence. It has also implemented and evaluated youth violence prevention programs, such as the Early Prevention of Violence Program in Medellín (16), where recent studies verified the association between exposure to violence in early life and increased violent behavior among adolescents (17). The Fontidueño House for Minors that Bejarano championed still exists today, under the guidance of Capuchin monks, as the San José School of Work (Escuela de Trabajo San José) (18). Other strategies developed elsewhere, such as health promotion practices in Brazil at the "School for Parents" program in Rio de Janeiro, and the Potentially Healthy Districts' Network (RMPS) in São Paulo State, have had a positive effect on their communities in terms of safety and the prevention of violence (19).

Based on his efforts to promote "prophylaxis" (prevention) of delinquent behaviors and recognition of the importance of social measures still considered relevant today, Bejarano was ahead of his time. For example, he recognized the effectiveness of home visitation as a tool for addressing child abuse and neglect, an intervention finally deemed effective in 1986 through Old and colleagues' use of modern epidemiological and statistical tools (20). He was also the first to promote the prevention of abuse and neglect as a tool to deal with delinquency 
in Colombia, an approach still promoted today in primary prevention of child maltreatment as a way to prevent violence. Although some of his underlying ideas about abuse and the development of delinquency are no longer espoused, his lecture in 1929 proves that elements of current ideas for dealing with child abuse and neglect were already well developed in the early 20th century. Many of the social interventions Bejarano highlighted are currently promoted as effective tools for the prevention of child maltreatment; he helped lay the foundations of these efforts by stressing the importance of the social context in modulating the occurrence of child abuse and neglect. Overall, Jorge Bejarano's views on protecting children from abuse and neglect to prevent criminality later in life are as relevant now as they were at the beginning of the 20th century.

Acknowledgements. This work was funded in part by a grant from the U.S. Centers for Disease Control and Prevention (CDC) National Center for Injury Prevention and Control (NCIPC) to The University of North Carolina Injury Prevention Research Center (R49/CCR402444). The authors express gratitude to Drs. Desmond K. Runyan and Elizabeth Tornquist for their review of this article and helpful suggestions.
SINOPSIS

\section{La delincuencia infantil y la profilaxis del crimen a principios del siglo $X X$ en América Latina}

A fin de ahondar en la visión que predominaba a principios del siglo XX sobre el maltrato infantil, sus efectos sobre el comportamiento de los jóvenes y las estrategias para prevenir la delincuencia juvenil se ofrece una sintesis en inglés de la conferencia "La delincuencia infantil y la profilaxis del crimen", presentada en 1929 por el pediatra e higienista social colombiano Jorge Bejarano Martínez y se resaltan sus teorías sobre el abuso y la desatención infantil, y la prevención del crimen. Mediante citas del texto original de 88 páginas, esta sintesis presenta los puntos de vista de Bejarano sobre las condiciones sociales que él consideraba cruciales en la etiología de la delincuencia infantil en Colombia (la falta de mecanismos sociales de protección y de oportunidades educacionales para los niños, la pobreza en el hogar, el trabajo infantil, el abandono, y el abuso y la desatención de los niños). Aunque en Colombia aún subsisten problemas de fondo similares, se han logrado avances en la protección de los niños contra el abuso y la desatención para prevenir la delincuencia en etapas posteriores de su vida. Esta conferencia demuestra que Bejarano fue un precursor de estos esfuerzos en América Latina y ofrece elementos sobre los orígenes de las estrategias actuales para reducir la violencia juvenil.

Palabras clave: historia, maltrato a los niños, violencia, crimen, Colombia.

\section{REFERENCES}

1. Roche AJ, Fortin G, Labbe J, Brown J, Chadwick D. The work of Ambroise Tardieu: the first definitive description of child abuse. Child Abuse \& Neglect. 2005;29(4):325-34.

2. Caffey J. Multiple fractures in the long bones of infants suffering from chronic subdural hematoma. AJR. 1946;53: $163-73$.

3. Silverman FN. The roentgen manifestations of unrecognized skeletal trauma in infants. AJR. 1953;69(3):413-27.

4. Kempe $\mathrm{CH}$, Silverman FN, Steele BF, Droegemueller W, Silver HK. The battered-child syndrome. JAMA. 1962; 181(1):17-24.

5. Bejarano J. La delincuencia infantil en Colombia y la profilaxis del crimen: conferencia dictada en el Teatro Municipal de Bogotá a beneficio de la Cruz Roja Nacional. Bogotá: Editorial Minerva; 1929.

6. Walsh C, MacMillan HL, Jamieson E. The relationship between parental substance abuse and child maltreatment: findings from the Ontario Health Supplement. Child Abuse \& Neglect. 2003; 27(12):1409-25.

7. Renneville M. L'anthropologie du criminel en France. Criminologie. 1994; 27(2):185-209.
8. Stanley LL. Disease and crime. J Crim Law Crim. 1923;14(130):103-9.

9. García-Latorre JM. Centros de menores en América visitados por Terciarios Capuchinos (1913-1959). Cologne (Germany): "Luis Amigó" Jugendhilfe e. V.; 2005.

10. Ibáñez PM. Crónicas de Bogotá. Book 1 , Chapter 1 [book on the Internet]. Bogotá: Imprenta Nacional; 1913 [cited 2008 April 21]. Available from: http:// www.lablaa.org/blaavirtual/historia/ cronidos/cap1.htm.

11. Brosse T. Problèmes d'éducation: l'enfance victime de la guerre. Une étude de la situation européenne. Paris: UNESCO; 1949. p. 147.

12. Gaitán Daza F. Multicausalidad, impunidad y violencia: una visión alternativa. Rev Econ Inst. 2001;3(5):78-105.

13. Krug EG, Dahlberg LL, Mercy JA, Zwi $A B$, Lozano R, editors. World report on violence and health. Geneva: World Health Organization; 2002.

14. Peden M, McGee K, Sharma G. The injury chart book: a graphical overview of the global burden of injuries. Geneva: World Health Organization; 2002.

15. Gutiérrez-Martínez MI, Espinosa-Del Vallín RE, Fandiño A, Oliver RL. The evaluation of a surveillance system for violent and non-intentional injury mor- tality in Colombian cities. Int J Inj Contr Saf Promot. 2007;14(2):77-84.

16. Duque LF, Orduz JF, Sandoval JdJ, Caicedo BE, Klevens J. Lecciones del programa de prevención temprana de la violencia, Medellín, Colombia. Rev Panam Salud Publica. 2007;21(1):21-9.

17. Mejia R, Kliewer W, Williams L. Domestic violence exposure in Colombian adolescents: pathways to violent and prosocial behavior. J Trauma Stress. 2006;19(2):257-67.

18. Religiosos Terciarios Capuchinos de Nuestra Señora de los Dolores [homepage on the Internet]. San Jose (Colombia): Religiosos Terciarios Capuchinos de Nuestra Señora de los Dolores; 2008 [cited 2008 July 18]. Escuela de Trabajo San José; [about 10 screens]. Available from: http://www.terciarioscapuchinossanjose.org/sanjose.htm.

19. Pereira Lima VL, Arruda JM, Barroso MA, Lobato Tavares MdF, Ribeiro Campos NZ, Zandonadil RC, et al. Analyzing the outcomes of health promotion practices. Promot Educ. 2007;Suppl 1: 21-6.

20. Olds DL, Henderson CR Jr, Chamberlin $R$, Tatelbaum R. Preventing child abuse and neglect: a randomized trial of nurse home visitation. Pediatrics. 1986;78(1): 65-78. 